\title{
Clinical Features of Cluster Headache without Cranial Autonomic Symptoms: Results from a Prospective multicentre study
}

\section{Min Kyung Chu}

Severance Hospital, Yonsei University

\section{Byung-Su Kim}

Bundang Jesaeng General Hospital

\section{Pil-Wook Chung}

Kangbuk Samsung Hospital: Kangbuk Samsung Medical Center

\section{Byung-Kun Kim}

Eulji University Hospital

\section{Mi Ji Lee}

Samsung Seoul Hospital: Samsung Medical Center

\section{Jeong Wook Park}

Uijeongbu Saint Mary's Hospital

Jin-Young Ahn

Seoul Medical Center

\section{Dae Woong Bae}

The Catholic University of Korea

\section{Tae-Jin Song}

Ewha Womans University Seoul Hospital

\section{Jong-Hee Sohn}

Chuncheon Sacred Heart Hospital

\section{Kyungmi Oh}

Korea University College of Medicine

\section{Daeyoung Kim}

Chungnam National University School of Medicine

\section{Jae-Moon Kim}

Chungnam National University College of Medicine and Graduate School of Medicine: Chungnam National University School of Medicine

\section{Soo-Kyoung Kim}

Gyeongsang National University College of Medicine

\section{Yun-Ju Choi}

De. Choi's Neurology Clinic 


\section{Jae Myun Chung}

Inje University College of Medicine

\section{Heui-Soo Moon}

Kangbuk Samsung Hospital: Kangbuk Samsung Medical Center

\section{Chin-Sang Chung}

Samsung Seoul Hospital: Samsung Medical Center

\section{Kwang-Yeol Park}

Chung-Ang University Hospital

Soo Jin Cho ( $\sim$ dowonc@naver.com )

Hallym University Dongtan Sacred Heart Hospital https://orcid.org/0000-0002-4053-3763

\section{Research article}

Keywords: anxiety, cluster headache, depression, cranial autonomic symptoms, prospective multicentre study

Posted Date: December 16th, 2020

DOI: https://doi.org/10.21203/rs.3.rs-127433/v1

License: (c) (i) This work is licensed under a Creative Commons Attribution 4.0 International License. Read Full License 


\section{Abstract}

Background: Although cranial autonomic symptoms are typical in cluster headache, some individuals with cluster headache show no cranial autonomic symptoms during their headache attacks. Probable cluster headache is a subtype of cluster headache that fulfils all but one of the five criteria for cluster headache. This study aimed to investigate the frequency and clinical features of cluster headache and probable cluster headache without cranial autonomic symptoms in comparison to those with cranial autonomic symptoms.

Methods: We analysed data from the Korea Cluster Headache Registry, a prospective multicentre registry involving data from 16 hospitals.

Results: Of the 216 participants with cluster headache and 26 with probable cluster headache, 19 (8.8\%) and 7 (26.9\%), respectively, did not have cranial autonomic symptoms. Participants with cluster headache without cranial autonomic symptoms exhibited less severe anxiety (General Anxiety Disorder-7 score, median [interquartile range], 2.0 [1.0-6.0] vs 8.0 [3.0-12.0], $p=0.001$ ) and depression (Patient Health Questionnaire-9 score, 3.0 [1.0-7.0] vs 7.0 [3.0-11.0], $p=0.042$ ) than those with cranial autonomic symptoms. Other clinical features, including headache intensity, daily headache frequency, attack duration, bout duration, and location of the pain, did not differ between participants with cluster headache with and without cranial autonomic symptoms. Headache intensity was less severe in participants with probable cluster headache without cranial autonomic symptoms than in those with cranial autonomic symptoms (numeric rating scale, 8.0 [7.0-8.0] vs 9.5 [8.0-10.0], $p=0.015$ ).

Conclusions: A significant proportion of participants with cluster headache and probable cluster headache did not have cranial autonomic symptoms. Some clinical features of cluster headache and probable cluster headache differed based on the presence of cranial autonomic symptoms.

\section{Background}

Cluster headache $(\mathrm{CH})$ is one of the most painful primary headache disorders. It is characterised by recurrent severe unilateral headache attacks and accompanied by ipsilateral cranial autonomic symptoms (CAS) [1, 2]. The term $\mathrm{CH}$ originates from the tendency of these headache attacks to cluster during bout periods that usually last for several weeks to months [3]. The third edition of the International Classification of Headache Disorders (ICHD-3) has divided the $\mathrm{CH}$ population into $\mathrm{CH}$ (code 3.1) and probable $\mathrm{CH}$ ( $\mathrm{PCH}$; code 3.5.1) [2]. $\mathrm{PCH}$ is a subtype of $\mathrm{CH}$ that fulfils all but one of the five criteria for $\mathrm{CH}$ and was reported to account for approximately $10-20 \%$ of $\mathrm{CH}$ cases $[2,4,5]$. Some clinical features of $\mathrm{PCH}$ differ from those of $\mathrm{CH}$. Individuals with $\mathrm{PCH}$ have a lower incidence of conjunctival injection and forehead sweating than those with $\mathrm{CH}$, but these groups have showed comparable disability $[5,6]$.

Although CAS have been recognised as typical symptoms of $\mathrm{CH}, 3-7 \%$ of individuals with $\mathrm{CH}$ were noted to never experience CAS during their $\mathrm{CH}$ attacks [7-9]. The frequency and clinical features of $\mathrm{CH}$ without CAS have been reported in only one study. A Portuguese study from a single university hospital reported 
in 2005 that headache intensity was less severe in individuals with $\mathrm{CH}$ without CAS than in those with CAS [7]. However, since this study did not distinguish between $\mathrm{CH}$ and $\mathrm{PCH}$ in its analysis, the frequency and clinical features of $\mathrm{CH}$ and $\mathrm{PCH}$ compared to those with CAS remain unclear. Furthermore, this study used data from a single hospital; thus, an additional analysis using data from various settings is needed to validate these findings.

This study aimed to assess (1) the frequencies of $\mathrm{CH}$ and $\mathrm{PCH}$ without $\mathrm{CAS}$ among participants with $\mathrm{CH}$ and $\mathrm{PCH}$ and (2) the differences in the clinical features of participants with $\mathrm{CH}$ and $\mathrm{PCH}$ with and without CAS. For this purpose, we used data from the Korean Cluster Headache Registry (KCHR), a prospective, multicentre registry of $\mathrm{CH}$.

\section{Methods}

\section{Study design and participants}

This descriptive, cross-sectional study aimed to investigate the frequency and clinical features of $\mathrm{CH}$ and $\mathrm{PCH}$ without CAS using data from the KCHR. The KCHR enrolled consecutive participants with $\mathrm{CH}$ aged $\geq 19$ years from 16 hospitals ( 14 university hospitals and two secondary referral general hospitals) in Korea. Participants were enrolled between September 2016 and December 2018.

Detailed information about the KCHR has been described previously $[5,10]$. In the $\mathrm{KCHR}$, participants fulfilling the diagnostic criteria for $\mathrm{CH}$ and $\mathrm{PCH}$ based on the beta version of the ICHD-3 (ICHD-3 beta), the available diagnostic criteria at the time, were enrolled. For the present study, we included participants fulfilling the diagnostic criteria for $\mathrm{CH}$ and $\mathrm{PCH}$ based on ICHD-3. A flow diagram of the participant selection process is presented in Fig. 1.

The KCHR collected data on the following parameters for all participants: sex, age at onset, body mass index, time from first headache onset to the diagnosis of $\mathrm{CH}$, headache intensity using a numeric rating scale (from 0 to 10), $\mathrm{CH}$ frequency, mean $\mathrm{CH}$ duration since the first episode, $\mathrm{CH}$ bout duration during the ictal period, total number of $\mathrm{CH}$ bouts, smoking history, impact of headache (Headache Impact Test- 6 [HIT-6] score), anxiety (General Anxiety Disorder-7 [GAD-7] score), and depression (Patient Health Questionnaire-9 [PHQ-9] score). Participants with a GAD-7 score of $\geq 10$ were classified as having anxiety [11], while participants with a PHQ-9 score of $\geq 10$ were classified as having depression $[12,13]$. The bout duration was defined as the duration between the first and last day of each cluster period. The cluster period was designated as cluster attacks occurring in a series persisting for weeks to months, separated by remission periods, usually lasting for several months or even years. The total number of bouts was defined as the total number of bouts (cluster periods) diagnosed as $\mathrm{CH}$. The history of migraine was evaluated in all participants. Investigators assessed the circadian and circannual rhythms by asking participants whether the attacks in the bout tended to occur at the same time of the day and year, respectively. 


\section{Diagnosis of cluster headache and probable cluster headache}

The diagnoses of $\mathrm{CH}$ and $\mathrm{PCH}$ were based on the ICHD-3 criteria. We further classified participants into one of the following groups based on the bout period duration: no definitive period, episodic, or chronic. Participants whose first episode of headache attacks fulfilled the $\mathrm{CH}$ or $\mathrm{PCH}$ criteria were classified, respectively, as having $\mathrm{CH}$ or $\mathrm{PCH}$ without a definitive period. Participants whose $\mathrm{CH}$ or $\mathrm{PCH}$ attacks lasted at least 1 year without a remission period or with remissions lasting $<3$ months were classified as having chronic $\mathrm{CH}(\mathrm{CCH})$ or $\mathrm{PCH}$, respectively. Participants whose $\mathrm{CH}$ or $\mathrm{PCH}$ attacks occurred in bouts (cluster periods), in whom two or more cluster periods lasted from 7 days to 1 year when untreated, and in whom cluster periods were separated by pain-free remission periods of $\geq 3$ months were classified as having episodic $\mathrm{CH}(\mathrm{ECH})$ or episodic $\mathrm{PCH}$.

\section{Case definitions of cluster headache and probable cluster headache without cranial autonomic symptoms}

According to the ICHD-3, we evaluated CAS in participants with $\mathrm{CH}$ and $\mathrm{PCH}$ based on the presence of the following conditions: (1) conjunctival injection and/or lacrimation, (2) nasal congestion and/or rhinorrhoea, (3) eyelid oedema, (4) forehead and facial sweating, and (5) miosis and/or ptosis. Since our study started in September 2016, when only the ICHD-3 beta was available, we also assessed the presence of (1) a sensation of fullness in the ear and (2) forehead and facial flushing, which were included as CAS in the ICHD-3 beta but not in the ICHD3.

\section{Ethical considerations}

The institutional review boards of the 16 participating hospitals approved this study. All participants provided written informed consent before study enrolment. All clinical investigations were conducted following the principles expressed in the Declaration of Helsinki.

\section{Statistical analyses}

The Kolmogorov-Smirnov test was used to evaluate the normality of data distribution. When a normal distribution was confirmed, Student's t-test or one-way analysis of variance was used to compare continuous variables. If a normal distribution was not confirmed, the Mann-Whitney Utest or KruskalWallis test was used, and values were expressed as medians (interquartile ranges). The chi-squared test was used to evaluate categorical variables. If an expected value was less than five, Fisher's exact test was used instead of the chi-squared test. Results were considered statistically significant when two-tailed $p$-values were less than 0.05 . The sample size was based on the available data. Statistical analyses were performed using IBM SPSS Statistics for Windows, Version 23.0 (IBM Corp., Armonk, NY, USA).

\section{Results}




\section{Participants}

A total of 251 participants were enrolled. One participant was excluded for not fulfilling the ICHD-3 criteria, and eight were excluded due to incomplete data. Finally, 216 participants with $\mathrm{CH}$ and 26 participants with PCH were included in this study (Fig. 1). The reasons for a diagnosis of PCH were as follows: an atypical attack duration $(n=8,30.7 \%)$, where the duration was longer $(n=6)$ or shorter $(n=2)$ than typical; missing accompanying symptoms $(n=6,23.1 \%) ;<5$ total number of attacks $(n=5,19.2 \%)$; $<1$ attack every other day $(n=3,11.5 \%)$; not a severe headache intensity $(n=2,7.7 \%)$; and a bilateral pain location $(n=2,7.7 \%)$. None of the participants with $\mathrm{CH}$ or PCH without CAS had a sensation of fullness in the ear or forehead and facial flushing, which were indicated as accompanying CAS in the ICHD-3 beta.

The frequencies of CAS in participants with $\mathrm{CH}$ and $\mathrm{PCH}$ are summarised in Table 1. Conjunctival injection and/or lacrimation was the most common CAS in participants with $\mathrm{CH}$, followed by nasal congestion and/or rhinorrhoea. Ptosis or miosis was the least common CAS. Similar patterns were seen in participants with $\mathrm{PCH}$, with conjunctival injection and/or lacrimation being the most common CAS and ptosis or miosis being the least common. 
Table 1

Distribution of cranial autonomic symptoms in the participants

\begin{tabular}{|c|c|c|c|c|c|}
\hline \multirow[t]{2}{*}{$\begin{array}{l}\text { Accompanying } \\
\text { symptoms }\end{array}$} & \multirow{2}{*}{$\begin{array}{l}\text { All participants } \\
\text { with } \mathrm{CH} \text { or } \mathrm{PCH} \\
n=242, n(\%)\end{array}$} & $\begin{array}{l}\mathrm{CH} \text { (code 3.1, } \\
\text { 3.1.1, and 3.1.2) }\end{array}$ & \multirow{2}{*}{$\begin{array}{l}\text { ECH } \\
\text { (code } \\
3.1 .1) \\
n=172, \\
n(\%)\end{array}$} & \multirow{2}{*}{$\begin{array}{l}\mathrm{CCH} \\
\text { (code } \\
3.1 .2 \text { ) } \\
\begin{array}{l}n=12, n \\
(\%)\end{array}\end{array}$} & \multirow{2}{*}{$\begin{array}{l}\mathrm{PCH} \\
\text { (code } \\
3.5) \\
n=26, \\
n(\%)\end{array}$} \\
\hline & & $n=216, n(\%)$ & & & \\
\hline \multicolumn{6}{|l|}{$\begin{array}{l}\text { Cranial autonomic } \\
\text { symptoms }\end{array}$} \\
\hline $\begin{array}{l}\text { Conjunctival injection } \\
\text { and/or lacrimation }\end{array}$ & 202 (83.5) & $187(86.6)$ & $\begin{array}{l}151 \\
(87.8)\end{array}$ & $11(91.7)$ & $\begin{array}{l}15 \\
(57.7)\end{array}$ \\
\hline $\begin{array}{l}\text { Nasal congestion } \\
\text { and/or rhinorrhoea }\end{array}$ & $134(55.4)$ & $123(56.9)$ & $\begin{array}{l}110 \\
(64.0)\end{array}$ & $3(25.0)$ & $\begin{array}{l}11 \\
(42.3)\end{array}$ \\
\hline Eyelid oedema & $64(26.4)$ & $60(27.8)$ & $\begin{array}{l}50 \\
(29.1)\end{array}$ & $3(25.0)$ & $4(15.4)$ \\
\hline $\begin{array}{l}\text { Forehead and facial } \\
\text { sweating }\end{array}$ & $68(28.1)$ & $66(30.6)$ & $\begin{array}{l}54 \\
(31.4)\end{array}$ & $5(41.7)$ & $2(7.7)$ \\
\hline Miosis and/or ptosis & $50(20.7)$ & $48(22.2)$ & $\begin{array}{l}39 \\
(22.7)\end{array}$ & $2(13.3)$ & $2(7.7)$ \\
\hline $\begin{array}{l}\text { Forehead and facial } \\
\text { flushing }\end{array}$ & $38(15.7)$ & $37(17.1)$ & $\begin{array}{l}34 \\
(19.8)\end{array}$ & $1(8.3)$ & $1(3.8)$ \\
\hline $\begin{array}{l}\text { Sensation of fullness in } \\
\text { the ear }\end{array}$ & $22(9.1)$ & $20(9.3)$ & $\begin{array}{l}19 \\
(11.0)\end{array}$ & $0(0.0)$ & $2(7.7)$ \\
\hline $\begin{array}{l}\text { No cranial autonomic } \\
\text { symptoms }\end{array}$ & $26(10.7)$ & $19(8.8)$ & $15(8.7)$ & $1(8.3)$ & $7(26.9)$ \\
\hline $\begin{array}{l}\text { A sense of restlessness } \\
\text { or agitation }\end{array}$ & $116(47.9)$ & 107 (49.5) & $\begin{array}{l}85 \\
(49.4)\end{array}$ & $8(66.7)$ & $9(34.6)$ \\
\hline
\end{tabular}

\section{Clinical features of all participants according to the presence of cranial autonomic symptoms}

The clinical features of all 242 participants are summarised in Table 2. The headache intensity was less severe in participants without CAS than in those with CAS. Anxiety (GAD-7 score $\geq 10$ ) and depression (PHQ-9 score $\geq 10$ ) were less prevalent in participants without CAS than in those with CAS. All other features were similar in participants with and without CAS. 
Table 2

Clinical features of participants with $\mathrm{CH}$ and $\mathrm{PCH}$ according to the presence of CAS

\begin{tabular}{|c|c|c|c|c|}
\hline & $\begin{array}{l}\text { Participants } \\
\text { with CH and } \\
\text { PCH } \\
n=242, n(\%)\end{array}$ & $\begin{array}{l}\text { Participants with } \\
\text { CH and PCH with } \\
\text { CAS } \\
n=216, n(\%)\end{array}$ & $\begin{array}{l}\text { Participants with } \mathrm{CH} \\
\text { and PCH without CAS } \\
n=26, n(\%)\end{array}$ & $\begin{array}{l}p- \\
\text { value }\end{array}$ \\
\hline Female & $37(15.3)$ & 33 (15.3) & $4(15.4)$ & 1.000 \\
\hline Age (year) & $\begin{array}{l}37(30.0- \\
44.0)^{\star}\end{array}$ & $37.0(30.3-43.8)^{\star}$ & $37.0(28.8-44.3)^{\star}$ & 0.822 \\
\hline Attack frequency per day & $37(15.3)$ & $33(15.3)$ & $4(15.4)$ & 0.409 \\
\hline $\begin{array}{l}\text { Headache intensity } \\
\text { (numeric rating scale) }\end{array}$ & $\begin{array}{l}37(30.0- \\
44.0)^{\star}\end{array}$ & $37.0(30.25-43.8)^{\star}$ & $37.0(28.75-44.3)^{\star}$ & 0.011 \\
\hline $\begin{array}{l}\text { Attack duration } \\
\text { (minutes) }\end{array}$ & 37 (15.3) & 33 (15.3) & $4(15.4)$ & 0.796 \\
\hline Migraine history & $33(13.6)$ & $30(14.30)$ & $3(11.5)$ & 1.000 \\
\hline Circadian rhythm & $134(55.4)$ & $121(56.0)$ & $13(50.0)$ & 0.560 \\
\hline Circannual rhythm & $219(90.5)$ & 198 (91.7) & $21(80.8)$ & 0.073 \\
\hline Current smoking & $106(43.8)$ & $99(45.8)$ & $7(26.9)$ & 0.066 \\
\hline \multicolumn{5}{|l|}{ Location of pain } \\
\hline Orbital & $193(79.8)$ & $174(80.6)$ & $19(73.1)$ & 0.370 \\
\hline Supraorbital & $121(50.0)$ & 112 (51.9) & $9(34.6)$ & 0.097 \\
\hline Temporal & $138(57.0)$ & $121(56.0)$ & $17(65.4)$ & 0.362 \\
\hline $\begin{array}{l}\text { Headache Impact Test- } 6 \\
\text { score }\end{array}$ & $\begin{array}{l}69.0(63.0- \\
75.0)^{\star}\end{array}$ & $69.0(63.0-75.0)^{\star}$ & $67.5(57.8-72.8)^{\star}$ & 0.259 \\
\hline $\begin{array}{l}\text { Anxiety (Generalized } \\
\text { Anxiety Disorder-7 score) }\end{array}$ & $\begin{array}{l}7.0(3.0- \\
11.0)^{\star}\end{array}$ & $7.0(3.0-12.0)^{\star}$ & $2.0(1.0-7.5)^{\star}$ & 0.001 \\
\hline $\begin{array}{l}\text { Generalized Anxiety } \\
\text { Disorder-7 score } \geq 10\end{array}$ & $87(36.0)$ & $83(38.8)$ & $4(15.4)$ & 0.018 \\
\hline $\begin{array}{l}\text { Depression (Patient } \\
\text { Health Questionnaire-9 } \\
\text { score) }\end{array}$ & $\begin{array}{l}6.0(3.0- \\
11.0)^{\star}\end{array}$ & $7.0(3.0-11.0)^{\star}$ & $4.0(2.0-7.3)^{\star}$ & 0.029 \\
\hline $\begin{array}{l}\text { Patient Health } \\
\text { Questionnaire-9 score } \geq \\
10\end{array}$ & $80(33.1)$ & $76(35.3)$ & $4(15.4)$ & 0.047 \\
\hline \multicolumn{5}{|c|}{ CAS: cranial autonomic symptoms, $\mathrm{CH}$ : cluster headache, $\mathrm{PCH}$ : probable cluster headache } \\
\hline Median and interquartile $r$ & & & & \\
\hline
\end{tabular}




\section{Clinical features of participants with cluster headache based on the presence of cranial autonomic symptoms}

Of the 216 participants with $\mathrm{CH}, 19$ (8.8\%) did not have CAS. Headache intensity, anxiety, and depression were less severe in participants with $\mathrm{CH}$ without CAS than in those with CAS. Other characteristics were not associated with the presence of CAS (Table 3). 
Table 3

Clinical features of participants with $\mathrm{CH}$ according to the presence of CAS

\begin{tabular}{|c|c|c|c|c|}
\hline & $\begin{array}{l}\text { Participants } \\
\text { with CH } \\
n=216, n \\
(\%)\end{array}$ & $\begin{array}{l}\text { Participants with } \\
\text { CH with CAS } \\
n=197, n(\%)\end{array}$ & $\begin{array}{l}\text { Participants with } \mathrm{CH} \\
\text { without CAS } \\
n=19, n(\%)\end{array}$ & $\begin{array}{l}p- \\
\text { value }\end{array}$ \\
\hline Female & $30(13.9)$ & $29(14.7)$ & $1(5.3)$ & 0.484 \\
\hline Age (year) & $\begin{array}{l}37.0(30.0- \\
44.0)^{*}\end{array}$ & $37.0(30.0-43.5)^{\star}$ & $38.0(25.0-45.0)^{\star}$ & 0.933 \\
\hline Attack frequency per day & $\begin{array}{l}1.5(1.0- \\
3.0)^{\star}\end{array}$ & $1.5(1.0-3.0)^{\star}$ & $1.5(1.0-2.5) \star$ & 0.686 \\
\hline $\begin{array}{l}\text { Headache intensity (numeric } \\
\text { rating scale) }\end{array}$ & $\begin{array}{l}9.0(8.0- \\
10.0)^{\star}\end{array}$ & $9.0(8.0-10.0)^{\star}$ & $9.0(8.0-10.0)^{\star}$ & 0.303 \\
\hline Attack duration (minutes) & $\begin{array}{l}90.0(60.0- \\
120.0)^{*}\end{array}$ & $90.0(60.0-120.0)^{*}$ & $120.0(60.0-120.0)^{*}$ & 0.581 \\
\hline Migraine history & $28(13.0)$ & $27(13.7)$ & $1(5.3)$ & 0.479 \\
\hline Circadian rhythm & $125(57.9)$ & $116(59.5)$ & $9(47.4)$ & 0.306 \\
\hline Circannual rhythm & $197(91.2)$ & $181(92.3)$ & $16(84.2)$ & 0.221 \\
\hline Current smoking & $98(45.4)$ & $91(46.2)$ & $7(36.8)$ & 0.434 \\
\hline \multicolumn{5}{|l|}{ Location of pain } \\
\hline Orbital & $172(79.6)$ & $158(80.2)$ & $14(73.7)$ & 0.500 \\
\hline Supraorbital & $109(50.5)$ & $102(51.8)$ & $7(36.8)$ & 0.214 \\
\hline Temporal & $120(55.6)$ & $110(55.8)$ & $10(52.6)$ & 0.788 \\
\hline Headache Impact Test- 6 score & $\begin{array}{l}69.0(63.0- \\
75.0)^{\star}\end{array}$ & $69.0(63.0-75.0)^{\star}$ & $70.0(64.0-76.0)^{\star}$ & 0.938 \\
\hline $\begin{array}{l}\text { Anxiety (Generalized Anxiety } \\
\text { Disorder-7 score) }\end{array}$ & $\begin{array}{l}7.0(3.0- \\
11.75)^{\star}\end{array}$ & $8.0(3.0-12.0)^{\star}$ & $2.0(1.0-6.0)^{\star}$ & 0.002 \\
\hline $\begin{array}{l}\text { Generalized Anxiety Disorder-7 } \\
\text { score } \geq 10\end{array}$ & $81(37.5)$ & $78(39.6)$ & $3(15.8)$ & 0.048 \\
\hline $\begin{array}{l}\text { Depression (Patient Health } \\
\text { Questionnaire-9 score) }\end{array}$ & $\begin{array}{l}6.0(3.0- \\
11.0)^{\star}\end{array}$ & $7.0(3.0-11.0)^{\star}$ & $3.0(1.0-7.0)^{\star}$ & 0.030 \\
\hline $\begin{array}{l}\text { Patient Health Questionnaire-9 } \\
\text { score } \geq 10\end{array}$ & $71(32.9)$ & $68(34.5)$ & $3(15.8)$ & 0.126 \\
\hline \multicolumn{5}{|c|}{ CAS: cranial autonomic symptoms, $\mathrm{CH}$ : cluster headache } \\
\hline *Median and interquartile range & & & & \\
\hline
\end{tabular}


Among the 172 participants with $\mathrm{ECH}, 15$ (8.7\%) did not have CAS. The mean duration of headache attacks was longer and anxiety and depression were less prevalent in participants with ECH without CAS than in those with CAS. Other clinical features were similar between participants with ECH with and without CAS (Table 4). Of the 12 participants with $\mathrm{CCH}$, two $(16.7 \%)$ did not have CAS. The frequencies of the absence of CAS in ECH and CCH were similar (8.7\% [15/172] vs 16.7\% [2/12], $p=0.612$, Table 4). 
Table 4

Clinical features of participants with ECH according to the presence of CAS

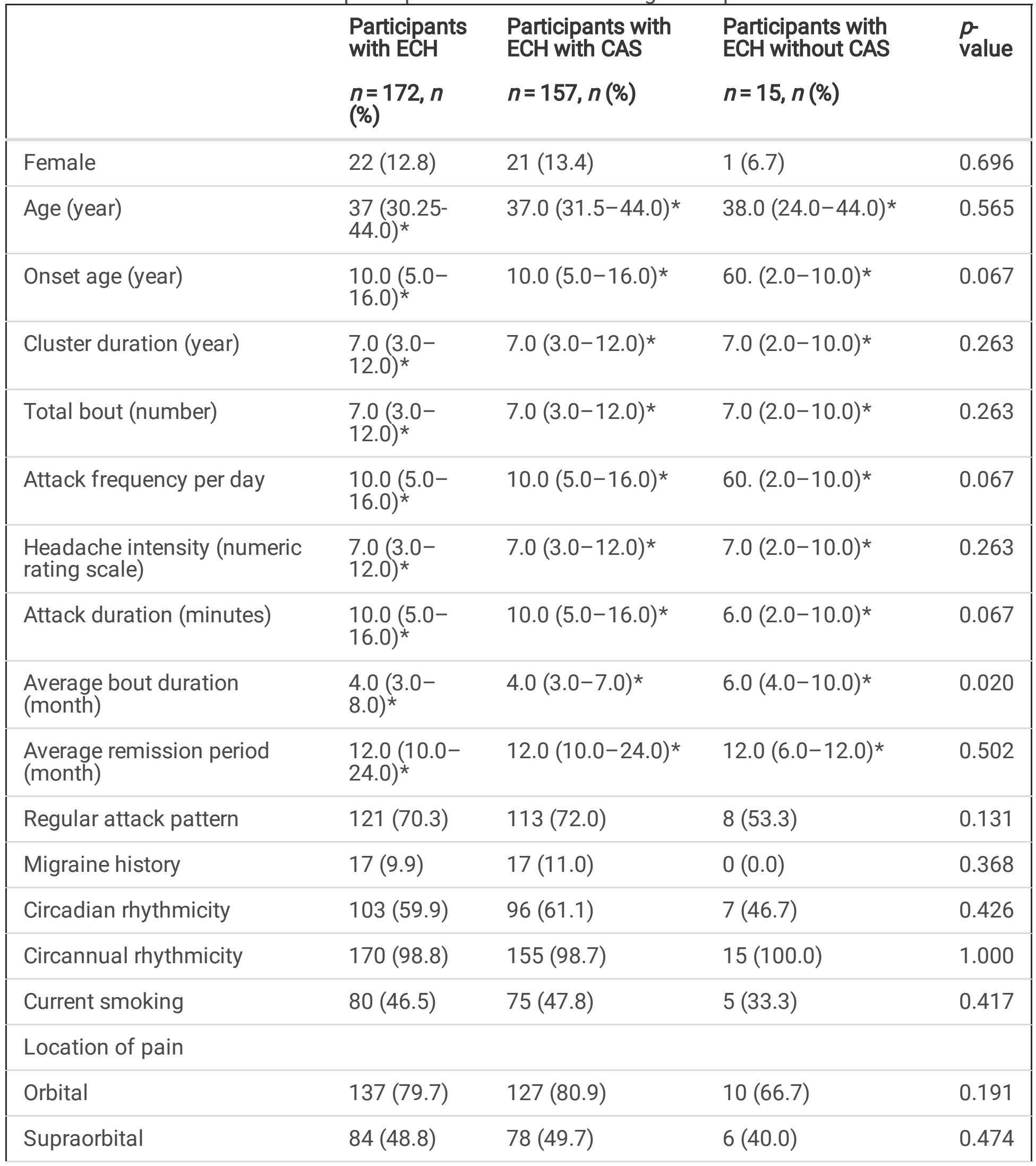

CAS: cranial autonomic symptoms, ECH: episodic cluster headache

*Median and interquartile range 


\begin{tabular}{|c|c|c|c|c|}
\hline & $\begin{array}{l}\text { Participants } \\
\text { with ECH } \\
\begin{array}{l}n=172, n \\
(\%)\end{array}\end{array}$ & $\begin{array}{l}\text { Participants with } \\
\text { ECH with CAS } \\
n=157, n(\%)\end{array}$ & $\begin{array}{l}\text { Participants with } \\
\text { ECH without CAS } \\
n=15, n(\%)\end{array}$ & $\begin{array}{l}p- \\
\text { value }\end{array}$ \\
\hline Temporal & $92(53.5)$ & $84(53.5)$ & $8(53.3)$ & 0.990 \\
\hline $\begin{array}{l}\text { Headache Impact Test- } 6 \\
\text { score }\end{array}$ & $\begin{array}{l}69.0(63.0- \\
75.0)^{*}\end{array}$ & $69.0(63.0-75.0)^{*}$ & $70.0(64.0-76.0) *$ & 0.938 \\
\hline $\begin{array}{l}\text { Anxiety (Generalized Anxiety } \\
\text { Disorder-7 score) }\end{array}$ & $\begin{array}{l}7.0(3.0- \\
11.8)^{\star}\end{array}$ & $8.0(3.0-12.0)^{\star}$ & $2.0(1.0-6.0)^{\star}$ & 0.002 \\
\hline $\begin{array}{l}\text { Generalized Anxiety Disorder- } \\
7 \text { score } \geq 10\end{array}$ & $81(37.5)$ & $78(39.6)$ & $3(15.8)$ & 0.048 \\
\hline $\begin{array}{l}\text { Depression (Patient Health } \\
\text { Questionnaire-9 score) }\end{array}$ & $\begin{array}{l}6.0(3.0- \\
11.0)^{\star}\end{array}$ & $7.0(3.0-11.0)^{\star}$ & $3.0(1.0-7.0)^{*}$ & 0.030 \\
\hline $\begin{array}{l}\text { Patient Health Questionnaire- } \\
9 \text { score } \geq 10\end{array}$ & $71(32.9)$ & $68(34.5)$ & $3(15.8)$ & 0.126 \\
\hline \multicolumn{5}{|c|}{ CAS: cranial autonomic symptoms, ECH: episodic cluster headache } \\
\hline *Median and interquartile ran & & & & \\
\hline
\end{tabular}

\section{Clinical features of participants with probable cluster headache based on the presence of cranial autonomic symptoms}

Of the 26 participants with PCH, 7 (26.9\%) did not have CAS. Headache intensity was less severe in participants with $\mathrm{PCH}$ without CAS than in those with CAS. The prevalence of anxiety and depression and other clinical features were similar in participants with PCH with and without CAS (Table 5). The frequency of not having CAS was higher in participants with $\mathrm{PCH}$ than in those with $\mathrm{CH}(26.9 \%[7 / 26]$ vs $8.7 \%[19 / 216], p=0.005)$. 
Table 5

Clinical features of participants with $\mathrm{PCH}$ according to the presence of CAS

\begin{tabular}{|c|c|c|c|c|}
\hline & $\begin{array}{l}\text { Participants } \\
\text { with PCH } \\
n=26, n(\%)\end{array}$ & $\begin{array}{l}\text { Participants with } \\
\text { PCH with CAS } \\
n=19, n(\%)\end{array}$ & $\begin{array}{l}\text { Participants with } \\
\text { PCH without CAS } \\
n=7, n(\%)\end{array}$ & $\begin{array}{l}p- \\
\text { value }\end{array}$ \\
\hline Female & $7(26.9)$ & $4(21.1)$ & $3(42.9)$ & 0.340 \\
\hline Age (year) & $\begin{array}{l}38.5(33.75- \\
43.25)^{\star}\end{array}$ & $40.0(35.0-44.0)^{\star}$ & $36.0(30 .-43.0)^{\star}$ & 0.534 \\
\hline Onset age (year) & $\begin{array}{l}32.0(28.75- \\
42.25)^{\star}\end{array}$ & $32.0(28.0-42.0) *$ & $36.0(29.0-43.0)^{*}$ & 0.572 \\
\hline Cluster duration (year) & $\begin{array}{l}1.0(0.0- \\
6.25)^{\star}\end{array}$ & $2.0(0.0-9.0)^{\star}$ & $1.0(0.0-3.0)^{*}$ & 0.427 \\
\hline Total bout (number) & $\begin{array}{l}1.5(1.0- \\
4.0)^{\star}\end{array}$ & $2.0(1.0-4.0)^{\star}$ & $1.0(1.0-2.0)^{\star}$ & 0.534 \\
\hline Attack frequency per day & $\begin{array}{l}1.0(1.0- \\
2.0)^{\star}\end{array}$ & $1.0(1.0-3.0)^{\star}$ & $1.0(1.0-2.0)^{\star}$ & 0.778 \\
\hline $\begin{array}{l}\text { Headache intensity (numeric } \\
\text { rating scale) }\end{array}$ & $\begin{array}{l}8.5(7.75- \\
10.0)^{\star}\end{array}$ & $9.5(8.0-10.0)^{\star}$ & $8.0(7.0-8.0)^{\star}$ & 0.015 \\
\hline Attack duration (minutes) & $\begin{array}{l}60.0(35.0- \\
180.0)^{\star}\end{array}$ & $60(30-195.0)^{\star}$ & $6.0(6.0-12.0)^{\star}$ & 0.790 \\
\hline $\begin{array}{l}\text { Average bout duration } \\
\text { (month) }\end{array}$ & $\begin{array}{l}3.5(2.25- \\
4.0)\end{array}$ & $4.0(2.0-4.0)^{\star}$ & $3.0(2.0-3.0)^{\star}$ & 0.727 \\
\hline $\begin{array}{l}\text { Average remission period } \\
\text { (month) }\end{array}$ & $\begin{array}{l}23.0(5.0- \\
29.0)\end{array}$ & $23.0(4.0-28.5)^{\star}$ & $12.0(6.0-12.0)^{\star}$ & $\begin{array}{l}> \\
0.999\end{array}$ \\
\hline Regular attack pattern & $6(23.1)$ & $5(26.3)$ & $1(14.3)$ & $\begin{array}{l}> \\
0.999\end{array}$ \\
\hline Migraine history & $5(19.2)$ & $3(15.8)$ & $2(28.6)$ & 0.588 \\
\hline Circadian rhythm & $9(34.6)$ & $5(27.8)$ & $4(571)$ & 0.205 \\
\hline Circannual rhythm & $22(84.6)$ & $1(5.6)$ & $2(28.6)$ & 0.180 \\
\hline Current smoking & $8(30.8)$ & $8(42.1)$ & $0(0.0)$ & 0.062 \\
\hline \multicolumn{5}{|l|}{ Location of pain } \\
\hline Orbital & $21(80.8)$ & $16(84.2)$ & $5(71.4)$ & 0.588 \\
\hline Supraorbital & $12(46.2)$ & $10(52.6)$ & $2(28.6)$ & 0.391 \\
\hline Temporal & $18(69.2)$ & $11(57.9)$ & $7(100.0)$ & 0.062 \\
\hline
\end{tabular}

CAS: cranial autonomic symptoms, $\mathrm{PCH}$ : probable cluster headache, *Median and interquartile range 


\begin{tabular}{|c|c|c|c|c|}
\hline & $\begin{array}{l}\text { Participants } \\
\text { with PCH } \\
n=26, n(\%)\end{array}$ & $\begin{array}{l}\text { Participants with } \\
\text { PCH with CAS } \\
n=19, n(\%)\end{array}$ & $\begin{array}{l}\text { Participants with } \\
\text { PCH without CAS } \\
n=7, n(\%)\end{array}$ & $\begin{array}{l}p- \\
\text { value }\end{array}$ \\
\hline $\begin{array}{l}\text { Headache Impact Test- } 6 \\
\text { score }\end{array}$ & $\begin{array}{l}65.5(57.0- \\
72.0)^{\star}\end{array}$ & $67.0(58.0-76.0)^{*}$ & $58.0(50.0-68.0)^{*}$ & 0.107 \\
\hline $\begin{array}{l}\text { Anxiety (Generalized Anxiety } \\
\text { Disorder-7 score) }\end{array}$ & $\begin{array}{l}5.0(2.0- \\
9.75)^{\star}\end{array}$ & $5.0(3.0-11.0)^{\star}$ & $4.0(3.0-8.0)^{*}$ & 0.455 \\
\hline $\begin{array}{l}\text { Generalized Anxiety Disorder- } \\
7 \text { score } \geq 10\end{array}$ & $6(23.1)$ & $5(26.3)$ & $1(14.3)$ & $>_{0.999}$ \\
\hline $\begin{array}{l}\text { Depression (Patient Health } \\
\text { Questionnaire-9 score) }\end{array}$ & $\begin{array}{l}5.0(2.0- \\
9.75)^{*}\end{array}$ & $5.0(3.0-11.0)^{*}$ & $4.0(3.0-8.0)^{*}$ & 0.455 \\
\hline $\begin{array}{l}\text { Patient Health Questionnaire- } \\
9 \text { score } \geq 10\end{array}$ & $6(23.1)$ & $5(26.3)$ & $1(14.3)$ & $\overrightarrow{0.999}$ \\
\hline
\end{tabular}

\section{Discussion}

The main findings of the present study were as follows: (1) Approximately one-eleventh of participants with $\mathrm{CH}$ and a quarter of those with PCH did not have CAS; (2) Anxiety and depression were less severe in participants with $\mathrm{CH}$ without CAS than in those with CAS; and (3) Headache intensity was milder in participants with $\mathrm{PCH}$ without CAS than in those with CAS. Other clinical features of $\mathrm{CH}$ and $\mathrm{PCH}$ did not differ between participants with and without CAS.

$\mathrm{CH}$ has been characterised by recurrent attacks of severe unilateral headache and ipsilateral CAS $[1,14]$. CAS were considered a key characteristic of $\mathrm{CH}$ and included as a diagnostic criterion since the publishing of the first edition of the ICHD $[8,15]$. Nevertheless, it has been reported that some individuals with $\mathrm{CH}$-like headaches did not experience CAS during headache attacks $[9,16]$. The second edition of the ICHD, published in 2004, included a sense of restlessness or agitation as an accompanying symptom of $\mathrm{CH}$, in addition to CAS, and a diagnosis of $\mathrm{CH}$ without CAS became possible [4]. The subsequent editions of diagnostic criteria for $\mathrm{CH}$ retained restlessness or agitation as an accompanying symptom along with CAS $[2,17]$. Therefore, $\mathrm{CH}$ and PCH without CAS are currently included in the ICHD-3, and our study enrolled participants based on these definitions.

We found that $8.8 \%$ of participants with $\mathrm{CH}$ did not have CAS. This frequency was similar or somewhat higher than that found in previous studies. A case series of 163 patients with $\mathrm{CH}$ in Sweden found that $3.1 \%$ did not have CAS [16], while an Italian clinic-based study of 251 patients with $\mathrm{CH}$ found that $2.8 \%$ did not have CAS [8]. Another Italian study found that $7.5 \%$ of patients with $\mathrm{CH}$ did not have CAS [9]. In a clinic-based study in Portugal, not having CAS was reported in $6.1 \%$ of patients with $\mathrm{CH}$ or $\mathrm{PCH}$ [7]. Possible causes for the discrepancy between the findings from our study and those from previous studies include differences in the diagnostic criteria, ethnicity, and study setting. The mentioned Swedish study 
used three criteria for $\mathrm{CH}$ diagnosis (World Federation of Neurology, Ekbom, and ICHD-1) [16, 18]. The two Italian studies used the ICHD-1, which did not include restlessness and agitation as accompanying symptoms. All four studies were conducted in European countries, while our study was conducted in Korea. Individuals with $\mathrm{CH}$ in Asian countries showed lower attack frequencies and shorter attack durations than those in Western countries [19]. All four previous studies used data from a single hospital, while the present study used data from the KCHR, which contained data from 16 hospitals.

It has been consistently reported that individuals with $\mathrm{CH}$ have a higher frequency of anxiety and depression than those with migraine or without headache [10, 20-24]. Additionally, it has been demonstrated that individuals with $\mathrm{CCH}$ are more likely to be affected by anxiety and depression than those with $\mathrm{ECH}$ [10]. High frequencies of anxiety and depression were observed in the $\mathrm{CH}$ and $\mathrm{PCH}$ groups in the present study. Furthermore, to the best of our knowledge, this study is the first to report that anxiety and depression were less severe in participants with $\mathrm{CH}$ without CAS compared to those with CAS. What is the possible mechanism underlying the association of anxiety and depression with CAS? One possible explanation is the role of shared anatomical substrates between the affective symptoms and $\mathrm{CH}$ in the pathogenesis of CAS. Neuroimaging findings have revealed an altered metabolism of the pain matrix and hypothalamus in patients with $\mathrm{CH}$ and affective disorders [25-27]. Therefore, decreased frequencies of anxiety and depression in participants with $\mathrm{CH}$ without CAS may be related to the roles of the pain matrix and hypothalamus in the pathogenesis of CAS. This hypothesis could be evaluated by comparing the neuroimaging findings between individuals with $\mathrm{CH}$ with and without CAS.

Conjunctival injection and/or lacrimation has been consistently reported to be the most common CAS in individuals with $\mathrm{CH}[8,28-30]$. In the present study, conjunctival injection and/or lacrimation, as the most frequent CAS, was observed in $86.6 \%$ of participants with $\mathrm{CH}$. Conjunctival injection and/or lacrimation was the most frequent CAS in Asian as well as Western countries [6, 19,31,32]. The frequency of CAS in the present study was similar to that found in previous studies from Asian countries. The frequency of ptosis or miosis in the present study (22.2\%) was lower than that found in studies from Western countries. A prospective clinical study in the UK found that $76 \%$ of individuals with $\mathrm{CH}$ had ptosis [30]. A Danish study reported that ptosis was present in $44.8 \%$ of patients with $\mathrm{CH}$ [29]. In Asian studies, a lower frequency of ptosis or miosis has been observed-a Japanese study showed a ptosis frequency of $8.1 \%$ [6], while a study at a Chinese tertiary headache centre revealed that ptosis or miosis was present in $16.7 \%$ of patients with $\mathrm{CH}$ [32] and a Korean multicentre study reported a rate of $8.5 \%$ [31]. The similarity in CAS frequencies mentioned above suggests that this parameter was correctly evaluated in the present study.

Our study had some limitations. First, it was conducted as a multicentre prospective study, but it did not represent the whole $\mathrm{CH}$ and $\mathrm{PCH}$ population. Therefore, our findings should be validated using another dataset to enhance the generalisability. Second, we included relatively small samples of patients with $\mathrm{PCH}$ and $\mathrm{CCH}$. Although we tried to enrol all eligible patients with $\mathrm{PCH}$ and $\mathrm{CCH}$ over the 3-year study period, the number of relevant cases may have been too small for some subgroup analyses. In other words, the statistical power was weakened by the limited sample size. Further studies that include a 
sufficient number of participants with $\mathrm{PCH}$ and $\mathrm{CCH}$ are needed to verify our findings. Third, we used the GAD-7 and PHQ-9 to assess anxiety and depression, respectively. However, these instruments only indicate a state of anxiety and depression and cannot be used to confirm the diagnosis. Additional analyses diagnosing anxiety and depression according to the fifth edition of the Diagnostic and Statistical Manual of Mental Disorders will confirm the relationship of anxiety and depression with CAS in $\mathrm{CH}$.

\section{Conclusions}

Among the participants with $\mathrm{CH}, 9 \%$ did not have CAS. The prevalence of anxiety and depression was lower in these patients than in those with CAS. Other clinical features were similar between participants with and without CAS. One-quarter of the participants with PCH did not have CAS and headache intensity was less severe in these participants than in those with CAS. The frequency of anxiety and depression did not differ between participants with PCH with and without CAS. Our study proposed that some clinical features of $\mathrm{CH}$ and $\mathrm{PCH}$ differed based on the presence of CAS. The findings of the present study will help to enhance the understanding of the pathophysiology of $\mathrm{CH}$.

\section{Abbreviations}

CAS: cranial autonomic symptoms; $\mathrm{CCH}$ : chronic cluster headache; $\mathrm{CH}$ : cluster headache; $\mathrm{ECH}$ : episodic cluster headache; GAD-7: Generalized Anxiety Disorder-7; HIT-6: Headache Impact Test-6; ICHD-3: The third edition of the International Classification of Headache Disorders; ICHD-3 beta: The third edition beta version of the International Classification of Headache Disorders; KCHR: Korean Cluster Headache Registry; PCH: probable cluster headache; PHQ-9: Patient Health Questionnaire-9.

\section{Declarations}

\section{Ethics approval and consent to participate}

The study protocol was approved by the ethics committee in each participating hospital and complied with the Declaration of Helsinki and Good Clinical Practice guidelines. All patients fully understood the study aims and gave written informed consent before participation.

\section{Consent for publication}

Not applicable.

\section{Availability of data and materials}

The data used in the present study are available from the corresponding author on reasonable request. 


\section{Competing interests}

Drs. BS Kim, PW Chung, BK Kim, MJ Lee, JW Park, JY Ahn, DW Bae, TJ Song, JH Sohn, K Oh, D Kim, JM Kim, SK Kim, YJ Choi, JM Chung, HS Moon, CS Chung, and KY Park declare that they have no competing interests.

Dr. SJ Cho was involved as a site investigator of a multicentre trial sponsored by Otsuka Korea, Eli Lilly and Co., and Novartis; functioned as an advisory member for Teva; and received research support from the Hallym University Research Fund 2016 and a grant from the Korean Neurological Association (KNA16-MI-09).

Dr. MK Chu was a site investigator for a multicentre trial sponsored by Otsuka Korea, Novartis, International AG, and Eli Lilly and Co. He functioned as an advisory member for Teva and received lecture honoraria from Allergan Korea, Handok-Teva, and Yuyu Pharmaceutical Company over the past 24 months. He received grants from the Yonsei University College of Medicine (2018-32-0037) and National Research Foundation of Korea (2019R1F1A1053841).

\section{Funding}

No financial relationships relevant to this publication were disclosed.

\section{Authors' contributions}

MKC and SJC conceptualised the idea and designed the study. BSK, PWC, BKK, MJL, JWP, MKC, JYA, DWB, TJS, JHS, KO, DK, JMK, SKK, YJC, JMC, HSM, CSC, KYP, and SJC contributed to data acquisition, analysis, and interpretation. MKC and SJC drafted the initial manuscript. PWC, BKK, MJL, JWP, MKC, JYA, DWB, TJS, JHS, KO, DK, JMK, SKK, YJC, JMC, HSM, and CSC made critical revisions to the manuscript with important intellectual content. All authors reviewed and approved the final manuscript. All authors agreed to be responsible for all aspects of the work and to ensure that questions related to the accuracy or integrity of any part of this work will be appropriately investigated and resolved.

\section{Acknowledgements}

Not applicable.

\section{References}

1. May A, Schwedt TJ, Magis D, Pozo-Rosich P, Evers S, Wang SJ (2018) Cluster headache. Nat Rev Dis Primers 4:18006. doi:10.1038/nrdp.2018.6

2. Headache Classification Committee of the International Headache Society (IHS). (2018) The International Classification of Headache Disorders, 3rd edition. Cephalalgia 38(1):1-211. 
doi:10.1177/0333102417738202

3. Nesbitt AD, Goadsby PJ (2012) Cluster headache. BMJ 344:e2407. doi:10.1136/bmj.e2407

4. Headache Classification Committee of the International Headache Society. (2004) The International Classification of Headache Disorders: 2nd edition. Cephalalgia 24 Suppl 1:9-160

5. Sohn JH, Choi YJ, Kim BK, Chung PW, Lee MJ, Chu MK, Ahn JY, Kim BS, Song TJ, Oh K, Lee KS, Kim SK, Park KY, Chung JM, Moon HS, Chung CS, Cho SJ, Park JW (2018) Clinical Features of Probable Cluster Headache: A Prospective, Cross-Sectional Multicenter Study. Front Neurol 9:908. doi:10.3389/fneur.2018.00908

6. Imai N, Yagi N, Kuroda R, Konishi T, Serizawa M, Kobari M (2011) Clinical profile of cluster headaches in Japan: low prevalence of chronic cluster headache, and uncoupling of sense and behaviour of restlessness. Cephalalgia 31(5):628-633. doi:10.1177/0333102410391486

7. Martins IP, Gouveia RG, Parreira E (2005) Cluster headache without autonomic symptoms: why is it different? Headache 45(3):190-195. doi:10.1111/j.1526-4610.2005.05043.x

8. Nappi G, Micieli G, Cavallini A, Zanferrari C, Sandrini G, Manzoni GC (1992) Accompanying symptoms of cluster attacks: their relevance to the diagnostic criteria. Cephalalgia 12(3):165-168. doi:10.1046/j.1468-2982.1992.1203165.x

9. Torelli P, Cologno D, Cademartiri C, Manzoni GC (2001) Application of the International Headache Society classification criteria in 652 cluster headache patients. Cephalalgia 21(2):145-150. doi:10.1046/j.1468-2982.2001.00185.x

10. Kim BS, Chung PW, Kim BK, Lee MJ, Park JW, Chu MK, Ahn JY, Bae DW, Song TJ, Sohn JH, Oh K, Kim D, Kim JM, Kim SK, Choi YJ, Chung JM, Moon HS, Chung CS, Park KY, Cho SJ (2020) The impact of remission and coexisting migraine on anxiety and depression in cluster headache. J Headache Pain 21(1):58. doi:10.1186/s10194-020-01120-7

11. Spitzer RL, Kroenke K, Williams JB, Löwe B (2006) A brief measure for assessing generalized anxiety disorder: the GAD-7. Arch Intern Med 166(10):1092-1097. doi:10.1001/archinte.166.10.1092

12. Choi HS, Choi JH, Park KH, Joo KJ, Ga H, Ko HJ, Kim SR (2007) Standardization of the Korean Version of Patient Health Questionnaire-9 as a Screening Instrument for Major Depressive Disorder. J Korean Acad Fam Med 28(2):114-119

13. Kroenke K, Spitzer R (2002) The PHQ-9: A New Depression Diagnostic and Severity Measure. Psychiatric Annals 32:509-521. doi:10.3928/0048-5713-20020901-06

14. Wei DY, Yuan Ong JJ, Goadsby PJ (2018) Cluster Headache: Epidemiology, Pathophysiology, Clinical Features, and Diagnosis. Ann Indian Acad Neurol 21(Suppl 1):S3-s8. doi:10.4103/aian.AIAN_349_17

15. Headache Classification Committee of the International Headache Society. (1988) Headache Classification Committee of the International Headache Society. Classification and diagnostic criteria for headache disorders, cranial neuralgias and facial pain. . Cephalalgia 8 Suppl 7:1-96

16. Ekbom K (1990) Evaluation of clinical criteria for cluster headache with special reference to the classification of the International Headache Society. Cephalalgia 10(4):195-197. doi:10.1046/j.14682982.1990.1004195.x

Page 19/22 
17. Headache Classification Committee of the International Headache Society. (2013) The International Classification of Headache Disorders, 3rd edition (beta version). Cephalalgia 33(9):629-808. doi:10.1177/0333102413485658

18. World Federation of Neurology Research Group on Migraine and Headache (1969) Classification of headache. J Neurol Sci 9(2):202

19. Peng KP, Takizawa T, Lee MJ (2020) Cluster headache in Asian populations: Similarities, disparities, and a narrative review of the mechanisms of the chronic subtype. Cephalalgia 40(10):1104-1112. doi:10.1177/0333102420923646

20. Donnet A, Lanteri-Minet M, Guegan-Massardier E, Mick G, Fabre N, Géraud G, Lucas C, Navez M, Valade D (2007) Chronic cluster headache: a French clinical descriptive study. J Neurol Neurosurg Psychiatry 78(12):1354-1358. doi:10.1136/jnnp.2006.112037

21. Louter MA, Wilbrink LA, Haan J, van Zwet EW, van Oosterhout WP, Zitman FG, Ferrari MD, Terwindt GM (2016) Cluster headache and depression. Neurology 87(18):1899-1906. doi:10.1212/wnl.0000000000003282

22. Robbins MS, Bronheim R, Lipton RB, Grosberg BM, Vollbracht S, Sheftell FD, Buse DC (2012) Depression and anxiety in episodic and chronic cluster headache: a pilot study. Headache 52(4):600611. doi:10.1111/j.1526-4610.2011.02024.x

23. Jürgens TP, Gaul C, Lindwurm A, Dresler T, Paelecke-Habermann Y, Schmidt-Wilcke T, Lürding R, Henkel K, Leinisch E (2011) Impairment in episodic and chronic cluster headache. Cephalalgia 31(6):671-682. doi:10.1177/0333102410391489

24. Robbins MS (2013) The psychiatric comorbidities of cluster headache. Curr Pain Headache Rep 17(2):313. doi:10.1007/s11916-012-0313-8

25. Buture A, Boland JW, Dikomitis L, Ahmed F (2019) Update on the pathophysiology of cluster headache: imaging and neuropeptide studies. J Pain Res 12:269-281. doi:10.2147/jpr.S175312

26. Yang FC, Chou KH, Kuo CY, Lin YY, Lin CP, Wang SJ (2018) The pathophysiology of episodic cluster headache: Insights from recent neuroimaging research. Cephalalgia 38(5):970-983. doi:10.1177/0333102417716932

27. Yoshino A, Okamoto Y, Doi M, Otsuru N, Okada G, Takamura M, Ichikawa N, Yokoyama S, Yamashita $\mathrm{H}$, Yamawaki S (2017) Regional brain functions in the resting state indicative of potential differences between depression and chronic pain. Sci Rep 7(1):3003. doi:10.1038/s41598-017-03522-1

28. Gouveia RG, Parreira E, Pavão Martins I (2005) Autonomic features in cluster headache. Exploratory factor analysis. J Headache Pain 6(1):20-23. doi:10.1007/s10194-005-0146-5

29. Snoer A, Lund N, Beske R, Hagedorn A, Jensen RH, Barloese M (2018) Cluster headache beyond the pain phase: A prospective study of 500 attacks. Neurology 91(9):e822-e831. doi:10.1212/01.wnl.0000542491.92981.03

30. Bahra A, May A, Goadsby PJ (2002) Cluster headache: a prospective clinical study with diagnostic implications. Neurology 58(3):354-361. doi:10.1212/wnl.58.3.354 
31. Moon HS, Park JW, Lee KS, Chung CS, Kim BK, Kim JM, Sohn JH, Chu MK, Oh K, Cho SJ (2017) Clinical Features of Cluster Headache Patients in Korea. J Korean Med Sci 32(3):502-506. doi:10.3346/jkms.2017.32.3.502

32. Dong Z, Di H, Dai W, Pan M, Li Z, Liang J, Zhang M, Zhou Z, Liu R, Yu S (2013) Clinical profile of cluster headaches in China - a clinic-based study. J Headache Pain 14(1):27. doi:10.1186/11292377-14-27

\section{Figures}

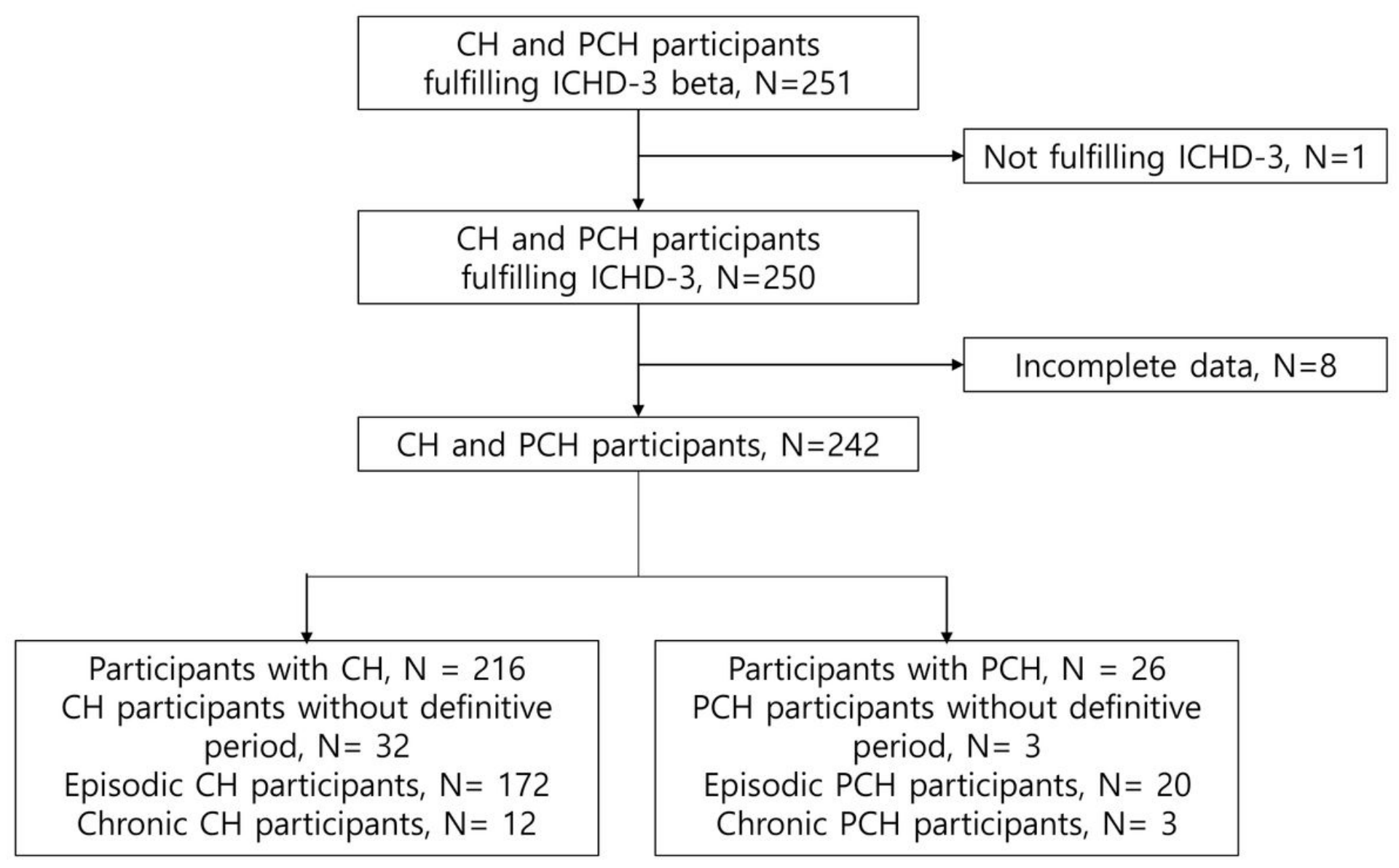

\section{Figure 1}

Flow diagram of participant selection $\mathrm{CH}$ : cluster headache, ICHD-3: The third edition of the International Classification of Headache Disorders, ICHD-3 beta: The third edition beta version of the International Classification of Headache Disorders, PCH: probable cluster headache 


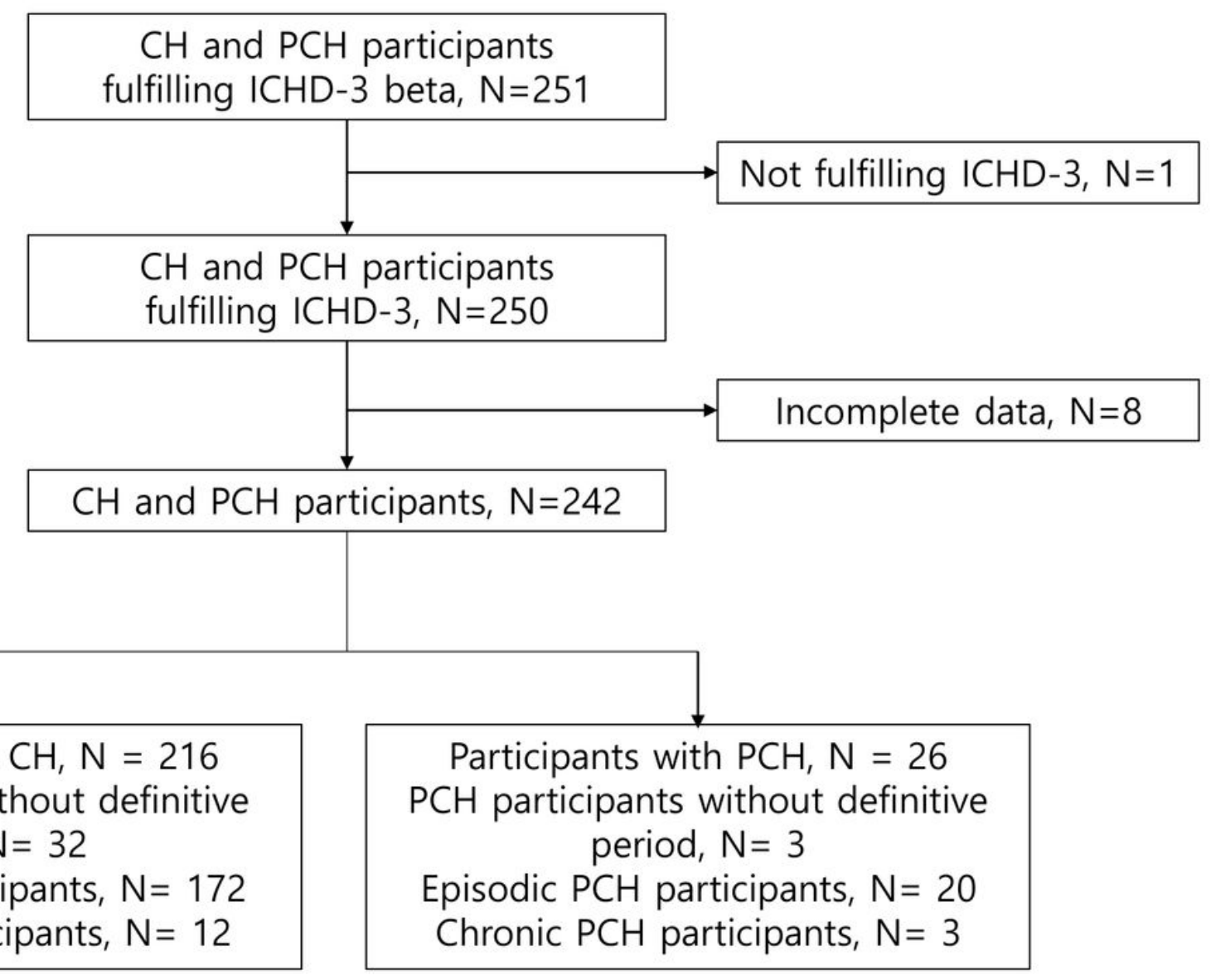

\section{Figure 1}

Flow diagram of participant selection $\mathrm{CH}$ : cluster headache, ICHD-3: The third edition of the International Classification of Headache Disorders, ICHD-3 beta: The third edition beta version of the International Classification of Headache Disorders, $\mathrm{PCH}$ : probable cluster headache 